\section{Ks. Paweł Podeszwa}

Uniwersytet im. Adama Mickiewicza, Poznań

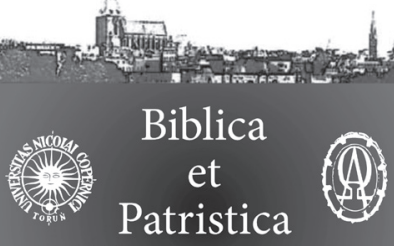

Thoruniensia

7 (2014) 3 ISSN 1689-5150

\title{
„Ewangelia Boga, obiecana od dawna przez proroków w Pismach Świętych" (Rz 1,2). Stary Testament w interpretacji Apostoła Pawła
}

\section{"The Gospel of God, promised beforehand through prophets in the Holy Scriptures" (Romans 1:2). The Old Testament as interpreted by the Apostle Paul}

Słowa klucze: Paweł; Stary Testament; List do Rzymian; obietnica; typologia; alegoria.

Keywords: Paul; the Old Testament; the Letter to the Romans; promise; typology; allegory.

Streszczenie. Artykuł jest poświęcony rozumieniu i interpretacji Starego Testamentu przez Apostoła Pawła. Nie tylko uznaje on autorytet Starego Testamentu jako Słowa Bożego, ale wypracowuje w swoich Listach pewne hermeneutyczne zasady dla relacji Starego Testamentu i dzieła zbawienia w Chrystusie, które następnie będą kontynuowane i rozwijane przez późniejszą tradycję chrześcijańską w interpretacji Biblii. Punktem wyjścia do prezentacji Pawłowego rozumienia Starego Testamentu jest początek „Listu do Rzymian”, gdzie Apostoł stwierdza, że Ewangelia Jezusa Chrystusa „została obiecana przez proroków w Pismach Świętych" $(1,2)$. To zdanie wskazuje, że Apostoł rozumie Stary Testament przede wszystkim jako obietnicę, którą należy odczytywać w świetle misterium paschalnego Jezusa. Jest to prehistoria Ewangelii, dzieła zbawczego w Jezusie oraz wiary chrześcijańskiej. Cały Stary Testament ma zatem wymiar prorocki, gdyż obwieszcza tajemnicę Chrystusa i ukierunkowuje historię zbawienia ku jej centrum i apogeum, którym jest Chrystus. W artykule zostały także omówione podstawowe zasady (klucze) hermeneutyczne (typologia, alegoria), proponowane i stosowane przez Pawła dla prawidłowego odczytania relacji Starego Testamentu i Chrystusa. Pozwalają one na zrozumienie ciągłości i jednolitości Bożego planu zbawienia, który Bóg wiernie i konsekwentnie realizuje.

Abstract. The article addresses the question of understanding and interpretation of the Old Testament by Apostle Paul. Paul does not only acknowledge the authority of the Old Testament as the Word of God but also devises in his Letters certain hermeneutical principles for the relation of the Old Testament and the work of salvation in Christ, 
which will then be continued and developed by the Christian tradition in the interpretation of the Bible. The basis for the presentation of Paul's understanding of the Old Testament is the beginning of "the Letter to the Romans", in which the Apostle states that the Gospel of Jesus Christ was "promised through prophets in the Holy Scriptures" (1:2). This sentence shows that the Apostle sees the Old Testament as first and foremost a promise, which should be interpreted in the light of the Paschal Mystery of Jesus. It is the prehistory of the Gospel, the work of salvation in Jesus and the Christian faith. The entire Old Testament has a prophetic dimension. It proclaims the mystery of Christ and directs the history of salvation towards its centre and climax- Christ himself. The article also contains the description of main hermeneutical principles (keys) such as typology and allegory, which are proposed and used by Paul in the correct interpretation of the relation of the Old Testament and Christ. They allow us to understand the continuity and uniformity of God's plan of salvation, which God faithfully and consistently fulfils.

$\mathrm{H}$ istoria interpretacji Biblii rozpoczyna się już w samej Biblii. Jedyna w swoim rodzaju spójność Księgi jest skutkiem faktu, że późniejsze teksty biblijne opierają się często na tekstach wcześniejszych, nawiązując do nich cytatami, aluzjami, a nade wszystko „relekturami”, które uwidoczniają nowe aspekty sensu, czasami różne od pierwotnego lub powołują się na nie wyraźnie, by pogłębić znaczenie albo potwierdzić ich spełnienie się. Te związki między tekstami stają się bardzo wyraziste w pismach Nowego Testamentu, które są nasycone aluzjami i cytatami do Pierwszego Testamentu ${ }^{38}$. Rzecz jasna, nie chodzi tylko i wyłącznie o bardziej lub mniej oczywiste materialne przywoływanie tekstów starotestamentowych ${ }^{39}$, ale przede wszystkim o interpretacje, którym zostały

38 Zob. Papieska Komisja Biblijna, Interpretacja Biblii w Kościele, s. 67-68 (IIIA1 oraz IIIA2); zob. także Papieska Komisja Biblijna, Naród żydowski, s. 16 (nr 3) : „Pisma Nowego Testamentu nigdy nie przedstawiają siebie jako coś kompletnie nowego. Przeciwnie, jawią się jako coś, co jest solidnie zakorzenione w długim doświadczeniu religijnym narodu Izraela, doświadczeniu spisanym w różnych formach w pismach sakralnych, które stanowią Pisma narodu żydowskiego". We wnioskach końcowych tego samego dokumentu prawda ta została wyrażona w sposób bardzo obrazowy, kiedy Papieska Komisja Biblijna stwierdza, że „bez Starego Testamentu Nowy Testament byłby księgą nie do rozszyfrowania, rośliną pozbawioną korzeni i skazaną na uschnięcie”, ibidem, s. 167 (nr 84).

39 Zob. P. Podeszwa, Memoria scripturarum, s. 8-12. Wspomniany już wcześniej dokument Papieskiej Komisji Biblijnej wskazuje na podstawowe sposoby zastosowania Starego Testamentu w Nowym. Mówi się o „licznych wyrażeniach zapożyczonych przez Nowy Testament z pism narodu żydowskiego, co prowadzi do częstych zjawisk reminiscencji i cytatów pośrednich, to znaczy całych zdań przejętych do Nowego Testamentu, bez wskazania pochodzenia danego cytatu" (Papieska Komisja Biblijna, Naród żydowski, s. 16 (nr 3). Obok reminiscencji i cytatów pośrednich występują także tak zwane cytaty wyraźne 
one poddane przez autorów Nowego Testamentu przy wykorzystaniu znanych i stosowanych ówcześnie metod egzegetycznych ${ }^{40}$. Zasadniczym novum było natomiast odczytywanie Starego Testamentu w świetle wydarzenie paschalnego, które nadało interpretowanym tekstom ostateczny i pełny sens. Sama „Biblia zawiera liczne wskazówki i sugestie na temat sztuki interpretacji. Faktycznie Biblia sama jest od początku interpretacją. Jej teksty zostały uznane przez społeczność Starego Testamentu i czasów apostolskich za prawdziwy wyraz ich wiary" ${ }^{41}$. Zatem już w Nowym Testamencie rozpoczyna się interpretacja Biblii, którą można by określić jako egzegeza „między dosłownością a alegorią" ${ }^{2}$. Wśród autorów Nowego Testamentu, którzy obficie korzystają ze Starego Testamentu jest Paweł $\mathrm{z}$ Tarsu ${ }^{43}$, wykształcony faryzeusz, znający nie tylko Pisma, ale także żydowskie metody egzegezy świętych tekstów (egzegeza aleksandryjska, qumrańska i rabiniczna) ${ }^{44}$. Zdaniem wielu komentatorów pism Apostoła

(bezpośrednie), to znaczy wprowadzone do Nowego Testamentu jako takie, z zaznaczeniem pochodzenia przywoływanego zapożyczenia. W przypadku tych ostatnich jest jasne, że autor wprost odnosi się do pism Starego Testamentu, najczęściej przez zastosowanie także formuły wprowadzającej cytat (formula quotationis), choć czasem jednoznaczne ustalenie konkretnego tekstu może też być problematyczne i niejednoznaczne. Jeszcze większe wyzwanie stanowi określenie pochodzenia cytatów pośrednich czy innego rodzaju reminiscencji, różnego stopnia aluzji i ech do Starego Testamentu. Doskonałym przykładem księgi biblijnej, która nie zawiera ani jednego cytatu bezpośredniego ze Starego Testamentu, ale mimo to pozostaje księgą najbardziej przesiąkniętą Starym Testamentem, jest Apokalipsa Janowa. Stary Testament jest w niej obecny przez charakterystyczne słownictwo, obrazy i tematy, zob. G.K. Beale, John’s Use; R.A. Pérez Márquez, L’Antico Testamento; M. Karczewski, Reinterpretacja Księgi Rodzaju,.

40 Zob. E.E. Ellis, Interpretacja Starego Testamentu, s. 49-58. Według Papieskiej Komisji Biblijnej, Interpretacja Biblii w Kościele, s. 43 (IC2), „różne metody egzegezy praktykowane przez judaizm o różnych tendencjach znajdują się w samym Starym Testamencie, na przykład w Księdze Kronik w odniesieniu do Ksiąg Samuela i Królewskich, a w Nowym Testamencie na przykład w niektórych argumentacjach skrypturystycznych św. Pawła. Różnorodność form (przypowieści, alegorie, antologie i centony, relektury, peszer, zbliżenia oddalonych tekstów, psalmy i hymny, wizje, objawienia i sny, kompozycje mądrościowe) jest wspólna dla Starego i Nowego Testamentu, jak również dla literatury wszystkich środowisk żydowskich przed Jezusem i po Jego czasach. Targumy i midrasze reprezentują homiletykę i interpretację biblijną licznych odłamów judaizmu pierwszych wieków".

41 Ibidem, s. 71 (IIIA3).

42 Zob. M. Simonetti, Między dosłownością a alegorią.

43 Zob. R.B. Hays, Echoes of Scripture in the Letters of Paul, New Haven-London 1989.

44 Zob. M. Silva, Stary Testament u Pawła, s. 779-792; R.A. Pérez Márquez, L’Antico Testamento, s. 73-85; J. Gnilka, Paweł, s. 263. 
Stary Testament, obok osobistego spotkania z Jezusem, otrzymanej łaski wiary oraz tradycji apostolskiej, stanowi jedno z głównych źródeł Pawłowej teologii ${ }^{45}$.

Przedmiotem refleksji jest nauczanie Apostoła Pawła, który nie tylko uznaje autorytet Starego Testamentu jako Słowa Bożego, ale wypracowuje w swoich Listach pewne hermeneutyczne zasady dla relacji Starego Testamentu i dzieła zbawienia w Chrystusie, które następnie będą stosowane i rozwijane przez późniejszą chrześcijańską tradycję interpretacji Bibliii ${ }^{46}$. Punktem wyjścia do prezentacji Pawłowego rozumienia Starego Testamentu czynimy początek „Listu do Rzymian", gdzie Apostoł stwierdza, że Ewangelia Jezusa Chrystusa została obiecana przez proroków w Pierwszym Testamencie $(1,2)$. W artykule zostaną omówione podstawowe zasady hermeneutyczne relacji Starego Testamentu i Chrystusa zastosowane przez Pawła (obietnica, typologia, alegoria) oraz ich znaczenie teologiczne.

\section{Początek „Listu do Rzymian"}

To niezwykle ważne pismo Pawłowe powstało w Koryncie podczas trzymiesięcznego pobytu Apostoła ( $\mathrm{Dz}$ 20,2b-3a), pod koniec trzeciej podróży misyjnej. Paweł zamieszkał w domu Gaiusa, w którym gromadziła się wspólnota chrześcijańska ( $\mathrm{Rz} 16,23)$ i stamtąd w miesiącach zimowych (luty - marzec)

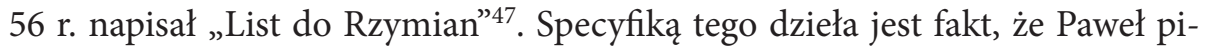
sze do wspólnoty chrześcijańskiej w stolicy imperium, której nie zakładał i nie znał osobiście, a wiedział o niej z relacji przybyłych z Rzymu Akwili i Pryscylii. Istotnym motywem napisania Listu był też zamiar zorganizowania wyprawy misyjnej do Hiszpanii. W drodze Paweł zamierzać odwiedzić Rzym, który miał stać się dla misji Pawłowej na Zachodzie tym, czym była Antiochia na Wscho$\mathrm{dzie}^{48}$. Paweł postanowił więc w Liście wyłożyć własne rozumienie Jezusowej Ewangelii, aby zapoznać wspólnotę stolicy cesarstwa ze swoją myślą i przygotować ją na zamierzony pobyt ${ }^{49}$. Pismo ma zatem „charakter traktatu dogmatycznego, streszczającego całą teologię Pawłową"50.

\footnotetext{
45 Zob. H. Langkammer, Apostoł Paweł, s. 229-234; J. Gnilka, Paweł, s. 255-268.

46 H. de Lubac, Pismo Święte.

47 Datację przyjmuję za W. Rakocy, Paweł Apostoł, s. 270-282.386. Autor podaje także opinie innych uczonych, którzy generalnie przyjmują napisanie „Listu do Rzymian” między rokiem 55 a 58 (s. 277-278).

48 Zob. A. Paciorek, Paweł Apostoł, s. 193.

49 Zob. S. Légasse, L’épître, s. 52.

50 T. Jelonek, Wprowadzenie, s. 57.
} 
Ten charakter „dogmatyczny” Listu jest widoczny od samego początku, kiedy w preskrypcie pisma umieszcza swoistego rodzaju glosę (dygresję, wtręt) na temat Ewangelii Jezusowej. Po pierwszym typowym elemencie adresu Listu, w którym nadawca przedstawia się jako „Paweł, sługa Chrystusa Jezusa, powołany Apostoł, przeznaczony do Ewangelii Bożej” (1,1), Autor zamieszcza krótką charakterystykę Ewangelii $(1,2-4)$ oraz swojej posługi $(1,5-6)$, aby dalej kontynuować preskrypt, zwracając się do adresatów: „wszystkim wam umiłowanym przez Boga w Rzymie, powołanym i świętym, łaska i pokój od Boga, Ojca naszego, oraz od Pana Jezusa Chrystusa" $(1,7)$. Graficznie można by to przedstawić w następujący sposób:

\section{$1,1 \quad$ NADAWCA \\ 1,2-6 EWANGELIA PAWŁOWA \\ $1,7 \quad$ ADRESACI}

\section{Stary Testament jako obietnica}

W Pawłowej charakterystyce Ewangelii na początku „Listu do Rzymian” odnajdujemy ważny element, który odnosi się do interesującego nas zagadnienia rozumienia przez Apostoła Starego Testamentu. Już w pierwszych słowach Paweł stwierdza, że jako powołany Apostoł, sam został przeznaczony (oddzielony) do

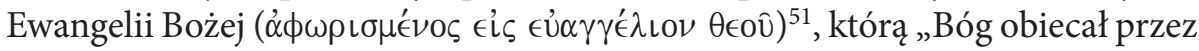

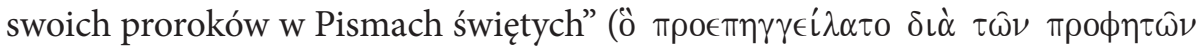

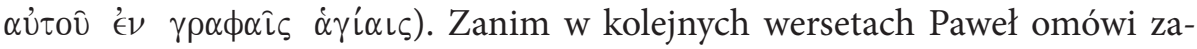
wartość Ewangelii rozpoczyna od stwierdzenia, że Stary Testament jest przede wszystkim obietnicą ( $\left(\epsilon \pi \alpha \gamma \gamma \in \lambda i^{\prime} \alpha\right)$ Ewangelii, która ma w nim swoją prehistorię, zarówno czasową jak i przyczynową, oraz jakościową ${ }^{52}$. Na tę prehistorię Ewangelii wskazuje także wymowna gra słów obecna w tekście greckim: Ewangelia

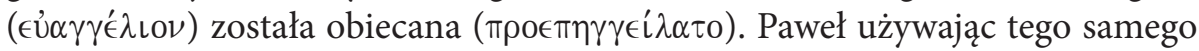

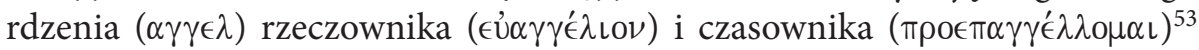
wyraża przekonanie, że Ewangelia, której stał się sługą, stanowiła treść obietnic starotestamentowych, stąd cały Stary Testament z jego historią zbawczą można

51 Zob. C. Korzec, Przeznaczony, s. 83-86; Św. Pawet - przeznaczony do Ewangelii, s. 82-93.

52 Zob. A. Pitta, Lettera, s. 47.

53 Czasownik ten występuje jeszcze tylko w 2 Kor 9,5. Wyraża idee antycypacji i pewności dzięki obietnicy, zob. R. Penna, Lettera, s. 92 z przypisem 45. 
uznać za obietnicę $e^{54}$ W ten sposób sam Jezus, Jego dzieło zbawcze oraz wiara chrześcijańska znajdują swoją prehistorię w Pierwszym Testamencie ${ }^{55}$. Zwróćmy jeszcze uwagę, że podmiotem czasownika „obiecywać” jest sam Bóg. Zatem wypowiedziane słowo - obietnica jest gwarantowana całkowicie autorytetem Boga, przeznaczona do wypełnienia, gdyż Bóg w szczególny sposób angażuje się $\mathrm{w}$ dane słowo ${ }^{56}$. Stary Testament jest przygotowaniem Ewangelii ${ }^{57}$, a „w tajemnicy Chrystusa wszystko jest zgodne z Pismami narodu żydowskiego. Przepowiadania pierwszych chrześcijan streszczało się w kerygmatycznej formule przytaczanej przez Pawła: «Przekazałem wam na początku to, co przejąłem, że Chrystus umarł zgodnie z Pismem - za nasze grzechy, że został pogrzebany, że zmartwychwstał trzeciego dnia zgodnie z Pismem - i że ukazał się Kefasowi, a potem Dwunastu» (1 Kor 15,3-5). Paweł dorzuca «Tak więc czy to ja, czy inni, tak nauczamy i tak uwierzyliście» (1 Kor 15,11). Wiara chrześcijańska nie bazuje zatem tylko na wydarzeniach, ale na zgodności tych wydarzeń z objawieniem zawartym w Pismach narodu żydowskiego" ${ }^{58}$.

Oczywiście dla poprawnego odczytanie tej podstawowej roli Starego Testamentu jako obietnicy „punktem wyjściowym jest Chrystus, jako pełna, doskonała i pozytywna odpowiedź na wszystkie Boże obietnice - epaggelia (2 Kor $1,20)$, co w konsekwencji oznacza, że Chrystus stanowi równocześnie koniec Prawa (Rz 10,4)"59. Stary Testament zawiera w sobie obietnice, które odnoszą się bezpośrednio do Chrystusa, ale także do Jego dzieła zbawczego oraz konsekwencji z niego płynących dla człowieka ${ }^{60}$. Jednym z zasadniczych tematów „Listu do Rzymian” jest wyjaśnienie nauczania Pawłowego o usprawiedliwieniu z wiary. Także w tym kontekście Apostoł wyraźnie stwierdza, że usprawiedliwienie $\mathrm{z}$ wiary zostało obiecane (zapowiedziane) w Pierwszym Testamencie. W Rz 3,21 czytamy, że „teraz objawiona została sprawiedliwość Boża niezależ-

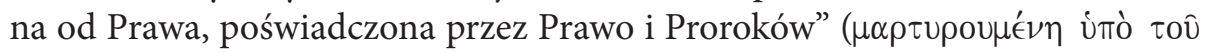

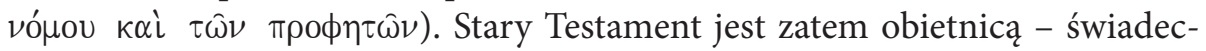

54 Zob. H. Langkammer, Jezus Chrystus, s. 31.

55 Zob. H. de Lubac, Pismo Święte, s. 181: „ «Historia» Starego Testamentu zapowiada «łaskę» Ewangelii".

56 Zob. S. Légasse, Lépître, s. 55.

57 R. Penna, Lettera, s. 91 uważa, że w Starym Testamencie Ewangelia ma „una preparazione in forma di assicurazione".

58 Papieska Komisja Biblijna, Naród żydowski, s. 21 (nr 7).

59 H. Langkammer, Jezus Chrystus, s. 30.

60 Warto zwrócić uwagę, że Paweł odnosi się do Starego Testamentu, mówiąc o własnym powołaniu i interpretując je w kontekście powołania prorockiego, zob. J. Gnilka, Pawet, s. 259; P. Podeszwa, Memoria scripturarum, s. 12-22 
twem nowej rzeczywistości, którą dokonała się w Jezusie. Została ona poświadczona (zaświadczona) przez „Prawo i Proroków”, to znaczy Stary Testament rozumiany całościowo. W zakończeniu „Listu do Rzymian” Paweł podkreśla, że Bóg jest wierny, a „Chrystus stał się sługą obrzezanych dla poświadczenia wierności Boga, aby potwierdzić obietnice dane ojcom oraz aby poganie za doznane miłosierdzie wielbili Boga" (Rz 15,8-9). Dlatego w 2 Kor 1,20 Paweł stwierdza jednoznacznie: „Wszystkie obietnice Boga w Nim stały się «tak»”. Historia opisana w Starym Testamencie jest rozumiana przez Pawła jako obietnica gwarantowana przez samego Boga, a zatem zmierzająca do wypełnienia się w Chrystusie, definitywnym Słowie - Dziele Boga. W ten sposób „czasowo i historycznie ST staje się nie tyle etapem przygotowawczym dla Ewangelii, ile początkiem z dynamicznym procesem, który swoje dopełnienie otrzymuje w Jezusie Chrystusie" 61 . Tylko w Nim i przez Niego można poprawnie odczytać objawienie zawarte w Starym Testamencie. W ten sposób zostaje usankcjonowana i zajmuje uprzywilejowane miejsce typowo chrześcijańska chrystologiczna relektura Pierwszego Testamentu ${ }^{62}$. Wymowną ilustracją tej prawdy jest wypowiedź Pawła, który pisząc o interpretacji żydowskiej Starego Testamentu stwierdza, że „Ich umysły jednak stępiały i po dziś dzień, kiedy czytają Stare Przymierze ( $\tau \hat{\eta} \varsigma \pi \alpha \lambda \alpha \iota \hat{\alpha} \varsigma \delta\llcorner\alpha \theta \eta \dot{\kappa} \kappa \eta \varsigma$ ) okrywa ich ta sama zasłona. Nie zostaje ona zdjęta, gdyż przemija ona w Chrystusie. Do dzisiaj, gdy czytają Mojżesza, zasłona zakrywa ich serca, chociaż on, kiedy zwracał się do Pana, zdejmował zasłonę" (2 Kor 3, 14-16). Warto zwrócić uwagę, że w kontekście tej wypowiedzi, dokładnie w 2 Kor 3,14, pojawia się jedyny raz u Pawła nazwa „Stare Przymierze” w sensie „Starego Testamentu”. Ponadto Paweł nawiązuje tutaj do Wj 34,34, kiedy to Mojżesz zdejmował zasłonę, aby rozmawiać z Bogiem. Jest to zapowiedź konieczności zwracania się do Pana, aby opadła zasłona, która nie pozwala żydom dostrzec sensu chrystologicznego Starego Testamentu. W zaproponowanej interpretacji Pawła „miejsce Jahwe zajmuje Pan Jezus Chrystus, a historia Mojżesza staje się historią Chrystusa"63.

\section{Stary Testament jako proroctwo}

Na początku „Listu do Rzymian” Paweł wyraźnie precyzuje, że Ewangelia Boża, będąca Dobrą Nowiną „o Jego Synu, pochodzącym według ciała z rodu Dawida,

61 H. Langkammer, List, s. 24; idem, Apostoł Paweł, s. 231 stwierdza: „Stary Testament jest jedną wielką Ewangelią, przekształconą w jedną wielką Ewangelię Jezusa Chrystusa”.

62 Zob. Papieska Komisja Biblijna, Naród żydowski, s. 38-40 (nr 19).

63 J. Gnilka, Pawet, s. 262. 
a ujawnionym według Ducha Świętego jako Syn Boży w mocy poprzez powstanie z martwych - o Jezusie Chrystusie Panu naszym" (Rz 1,3-4) została obiecana przez proroków ( $\delta i \dot{\alpha} \tau \hat{\omega} \nu \pi \rho \emptyset \emptyset \tau \omega \hat{\omega} \nu)$. Paweł nie odnosi się do konkretnych tekstów prorockich, nie myśli także o księgach prorockich w ogólności ${ }^{64}$, które stanowiły drugą część TaNaKu (Tanach) ${ }^{65}$ (np. „Prawo i Prorocy” w Rz 3,21), ale Apostoł uznaje cały Stary Testament za prorocki, to znaczy zapowiadający (wieszczący) Chrystusa i Jego działo zbawcze (Rz 16,26) ${ }^{66}$. Wymownym potwierdzeniem jest fakt, że przecież w swoich pismach Paweł odwołuje się do różnych ksiąg Starego Testamentu ${ }^{67}$, a w „Liście do Rzymian” jako przykład usprawiedliwienia $\mathrm{z}$ wiary, po nawiązaniu do Ha $2,4 \mathrm{w} \mathrm{Rz} 1,17^{68}$, przywoła postać i historię Abrahama (4,1-25) z Księgi Rodzaju. Zresztą trzeba także zaznaczyć, że w Corpus Paulinum „List do Rzymian” zawiera największą liczbę cytatów ze Starego Testamentu. Warto tu także przytoczyć Rz 16,25-27, gdzie w doksologii końcowej Listu Apostoł zamieszcza hymn pochwalny na cześć Boga: „A Temu, który ma moc utwierdzić was zgodnie z moją Ewangelią i z głoszeniem Jezusa Chrystusa, zgodnie z objawieniem owej tajemnicy, która dla dawnych czasów była zakryta, a teraz została objawiona według postanowienia wiecznego Boga, a przez pisma prorockie obwieszczona ( $\phi \alpha \nu \in \rho \omega \theta \epsilon \in \tau \tau \varsigma$

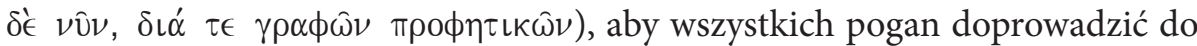
posłuszeństwa $w$ wierze, Jemu, który jedynie jest mądry - Bogu niech będzie chwała przez Jezusa Chrystusa na wieki wieków! Amen”.

\section{Stary Testament jako Pisma Święte}

Stwierdzenie Apostoła, że Bóg obiecał Ewangelię „przez proroków w Pismach

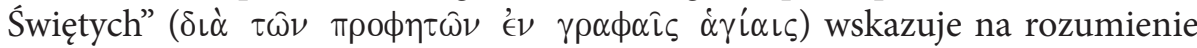
przez Pawła Starego Testamentu jako „Pism Świętych”.

Najpierw są to „Pisma”. Kolejny raz mamy potwierdzenie, że chodzi o Stary Testament rozumiany globalnie, na co wyraźnie wskazuje liczba mnoga

64 Zob. C.M. Robeck, Proroctwo, s. 652.

65 Jest to skrót określający Biblię Hebrajską, utworzony od początkowych liter trzech części Pisma: Tora („Prawo”), Newiim („Prorocy”), Ketuwim („Pisma”), zob. A. Unterman, Encyklopedia, s. 284.

66 Zob. R. Penna, Lettera, s. 91, zwłaszcza przypis 43.

67 Szczegółowe zestawienie cytatów ze Starego Testamentu u Pawła, zob. M. Silva, Stary Testament u Pawła, s. 780-781. 
rzeczownika ${ }^{69}$. Paweł ma świadomość, że chodzi o Słowo Boże, które zostało spisane na przestrzeni wieków i jako takie stanowi dziedzictwo chrześcijan. Jedynie w Rz 1,2 dodatkowo rzeczownik „Pisma” zostaje określony jako „Święte”. Analogiczne określenie znajduje się w 2 Tm 3,15, gdzie mowa o „Świętych

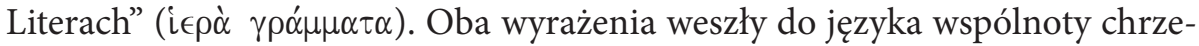
ścijańskiej poprzez literaturę żydowską i grecką, zwłaszcza Filona Aleksandryjskiego ${ }^{70}$. Użyty przymiotnik pozwala jednoznacznie odnieść Pisma do Boga. On jest ich źródłem (podmiotem) i jednocześnie one zawierają Jego obietnice. W ten sposób Paweł uznaje autorytet Starego Testamentu jako Pisma Bożego. Potwierdzeniem tego przekonania są liczne odniesienia (nie tylko cytaty bezpośrednie) do Starego Testamentu wprowadzone przy pomocy formy czasownikowej „jest napisane" ( $\left.\gamma^{\prime} \gamma_{\rho} \alpha \pi \tau \alpha \iota\right)$ w Rz 1,17; 2,24; 3,4.10; 4,17; 8,36; 9,13.33; $10,15 ; 11,8.26 ; 12,19 ; 14,11 ; 15,3.9 .21)$, rzeczownikiem „Pismo” w liczbie pojedynczej (ं $\gamma \rho \alpha \phi \eta$,) w Rz 4,3; 9,17; 10,11; 11,2; 15,10 lub w liczbie mnogiej w Rz 15,4; 16,26. Jak stwierdza o. Langkammer, „są to terminy techniczne judaizmu w określeniu kanonu Starego Testamentu. Posługując się tymi terminami, Paweł aprobuje kanon Starego Testamentu"71. Ponadto cytaty ze Starego Testamentu są wprowadzane przy pomocy formuł: „Dawid mówi” ( $\Delta \alpha v i \delta \delta$ $\lambda \epsilon \in \epsilon$ )

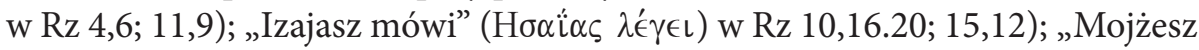

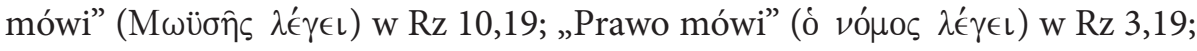

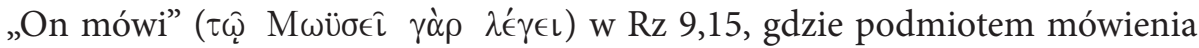
jest domyślnie sam Bóg. Nawet jeśli Paweł wymienia różne osoby, pismo(a), Prawo $^{72}$ które mówią, to ma świadomość, że zawsze jest to mowa samego Boga, a tym samym „równą wagę i równy autorytet przypisuje wszystkim słowom Starego Testamentu"73.

69 Paweł używa także terminu „Prawo” i odnosi go do całego objawienia Starego Testamentu. Przykładem może być 1 Kor 14,21, gdzie Paweł cytuje Iz 28,11 wprowadzając cytat

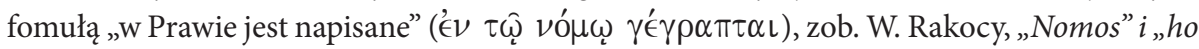
nomos" w Liście do Rzymian, s. 12 [11-23]; idem, Nomos i ho nomos w listach Pawłowych, s. $167-184$.

70 Zob. G. Shrenk, $\gamma \rho \alpha ́ \phi \omega$, k. 627-628; A. Pitta, Lettera, s. 47.

71 H. Langkammer, Jezus Chrystus, s. 28.

72 Także tutaj „Prawo” należy rozumieć szeroko jako całość starotestamentowego objawienia.

73 Ibidem, s. 29. 


\section{Pawłowe klucze hermeneutyczne: typologia i alegoria}

Skoro Stary Testament jest obietnicą samego Boga zapisaną (objawioną i jednocześnie jeszcze ukrytą) w świętych księgach, odnoszącą się Chrystusa i Jego zbawczego dzieła, to w jaki sposób odczytywać Pierwsze Przymierze, aby uchwycić ową dynamiczną relację między obietnicą a jej realizacją? Innymi słowami, jest to pytanie o chrześcijańską interpretację Starego Testamentu. I chociaż u Pawła nigdy nie znajdziemy rozważań egzegetycznych w zwykłym sensie tego słowa, ani żadnego systematycznego wykładu na ten temat ${ }^{74}$, to jednak ze sposobu, w jaki Apostoł przywołuje i komentuje teksty starotestamentowe możemy wywnioskować zręby jego metody czy raczej kluczy hermeneutycznych, których używa od nowego odczytania Pierwszego Testamentu.

Pierwszym z nich jest niewątpliwie typologia, którą Apostoł stosuje w swoich Listach. Według definicji zaproponowanej przez Hanson, jest to „metoda, stosowana w Nowym Testamencie i we wczesnym Kościele, polegająca na uznaniu jakiejś osoby albo wydarzeń starotestamentowych za typy albo zapowiedzi jakiejś osoby (prawie zawsze Chrystusa) albo jakiegoś znamiennego elementu czy charakterystycznego rysu religii chrześcijańskiej”75. Stąd „celowość hermeneutyczna typologii jest podobna do obietnicy. Urzeczywistnienie się typu (prefigury) w nowej ekonomii zbawczej - oczywiście w Jezusie i przez Niego - świadczy o tym, że Stary Testament miał charakter chrystoperspektywiczny (nie chrystocentryczny)"76. Wszystkie typy starotestamentalne przywołane w Nowym Testamencie i odniesione do nowych rzeczywistości, określanych

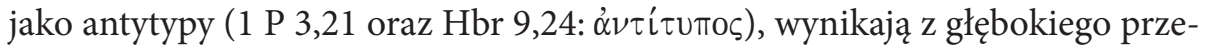
konania, że istnieje jeden ciągły plan Boży, w którym Stary Testament jest „prefiguracją" tego wszystkiego, co Bóg uczynił w Nowym ${ }^{77}$. Taka relektura Starego Testamentu w Nowym podkreśla także jedności całej Biblii ${ }^{78}$.

74 Zob. M. Silva, Stary Testament u Pawła, s. 789.

75 A.T. Hanson, Typologia, s. 780.

76 H. Langkammer, Apostoł Pawet, s. 231.

77 Zob. B. McNeil, Typologia, s. 894. Warto także zaznaczyć, że typologia była już stosowana w Starym Testamencie, zob. H. Langkammer, Jezus Chrystus, s. 31-32. Według M. Simonetti, Między dosłownością a alegorią, s. 22 „typ” oznacza „figurę, formę, symbol, prefigurację" i jest terminem używanym przez Pawła na przejście między dwoma poziomami lektury tekstu: literalnej oraz typologiczno-alegoryzującej. Termin ten nie miał takiego znaczenia egzegetycznego ani w literaturze greckiej, ani u zhellenizowanych Żydów.

78 Zob. M. Grilli, Quale rapporto, s. 39-42. Włoski egzegeta pisze o modelu typologiczno-alegorycznym w chrześcijańskim rozumieniu jedności całej Biblii. Na ten temat zob. 
Często mówi się o trojakiej typologii: osobowej, wydarzeniowej oraz instytucjonalnej ${ }^{79}$. W myśli Pawła ważną rolę odgrywa zwłaszcza typologia osobowa. Wymownym przykładem takiego sposobu interpretacji Starego Testamentu jest Pawłowa chrystologia "Adama” ${ }^{20}$. W Rz 5,14 czytamy, że „On jest

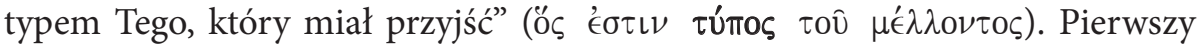
Adam jest zatem typem (obietnicą) drugiego Adama - Chrystusa. Dodatkowo Apostoł dokonuje zestawienia obu postaci, porównania, które staje się antytezą: „A zatem, jak z powodu występku jednego człowieka wyrok potępiający dotknął wszystkich ludzi, tak też z powodu jednego czynu usprawiedliwiającego do wszystkich ludzi przyszło usprawiedliwienie dające życie. Bo jak przez nieposłuszeństwo jednego człowieka wielu stało się grzesznikami, tak przez posłuszeństwo jednego wielu stanie się sprawiedliwymi” (Rz 5,18-19). W „Liście do Rzymian" innym przykładem typologii osobowej jest postać Abrahama jako typu człowieka, który osiąga usprawiedliwienia z wiary ( $\mathrm{Rz} 4,1-25)$, przez co patriarcha stal się ojcem wszystkich wierzących $(\mathrm{Rz} 4,16-17)^{81}$.

Paweł odwołuje się także chętnie do typologii instytucjonalnej. Przykładem może być nazwanie Chrystusa „ołtarzem przebłagania” („narzędziem przebłagania”, „przebłagalnią”) w Rz 3,25. Jest to nawiązanie do Dnia Pojednania, kiedy arcykapłan skrapiał krwią ofiar wieko Arki Przymierza, zwane przebłagalnią. Według Pawła ryt ten jest typem (zapowiedzią) doskonałego oczyszczenia z grzechów, które dokona się w krzyżowej śmierci Jezusa. Podobną typologię stosuje Apostoł w odniesieniu do Przymierza na Synaju, które jest prefiguracją Nowego Przymierza w Jezusie Chrystusie (2 Kor 3,4-18).

Zdaniem o. Langkammera, „za przykład typologii wydarzeniowej może służyć wędrówka Izraela po pustyni. Tu typologia staje się przestrogą, by nie postępować tak, jak postępowali Żydzi na pustyni. Wydarzenia, jak: obłok, przejście przez może, spożywanie manny, picie wody ze skały, były cudowne

także Papieska Komisja Biblijna, Naród żydowski, s. 40-41 (punkt 20 o relekturze alegorycznej, gdzie mówi się także o typologii).

79 H. Langkammer, Apostoł Pawet, s. 231.

80 E.E. Ellis, Interpretacja Starego Testamentu, s. 56 określa tę typologię mianem „typologii stworzenia".

81 Zob. H. Langkammer, Jezus Chrystus, s. 32-33. Według J. Gnilka, Paweł, s. 263 Paweł posługuje się tutaj regułą rabinacką (siódmą regułą interpretacyjną Hillela), określającą wnioskowane na podstawie miejsca danej wypowiedzi w jej kontekście: Abraham najpierw otrzymał od Boga obietnicę swego usprawiedliwienia ( $\mathrm{Rdz} 15,6)$, a dopiero potem pieczęć obrzezania ( $\mathrm{Rdz} 17)$. Z tego czasowego prae Paweł wyprowadza wniosek o pierwszeństwie wiary w stosunku do obrzezania. Abraham jest ojcem wierzących, a nie ojcem obrzezanych, czyli żydów. Ta argumentacja musiała być przekonująca dla obeznanych z egzegezą rabinacką. 
i wskazywały na Chrystusa («a tą skałą był Chrystus»), ale postawa Żydów (szemranie, bałwochwalstwo, rozpusta itp.) nie pozwoliła im odczytać tego, co «przydarzyło się im jako zapowiedź rzeczy przyszłych, spisane zaś zostało ku pouczeniu nas, których dosięga kres czasów» (1 Kor 10,11)"82. Warto zwrócić uwagę, że w zacytowanym zdaniu Pawła pojawią się także termin techniczny

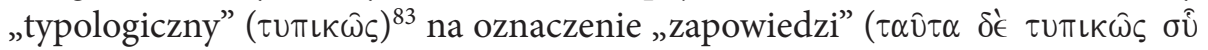

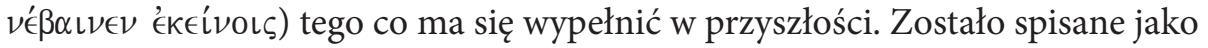
pouczenie i przestroga $(\nu \circ \cup \theta \epsilon \sigma i \alpha)$ dla żyjących w czasach ostatecznych. Istnieje zatem ścisła zależność i kontynuacja pomiędzy przeszłością i teraźniejszością, między historią narodu wybranego a dziejami wyznawców Jezusa ${ }^{84}$. Przywoływane wydarzenia ze Starego Testamentu są odczytywane i aktualizowane w odniesieniu do teraźniejszości chrześcijan. Na koniec warto zwrócić uwagę, że w interpretacji typologicznej proponowanej przez Apostoła Pawła „nakładają się dwa poziomy lektury: jeden odnoszący się do starotestamentalnego wydarzenia historycznego, drugi ukazujący nowe wydarzenie dotyczące rzeczywistości Chrystusa i Kościoła, których wydarzenie starożytne stanowiło prefigurację, prorocką i symboliczną antycypację" ${ }^{\prime 5}$. Mamy zatem dwa poziomy: sens wyrazowy i typologiczny oraz charakterystyczne przejście między dwoma po-

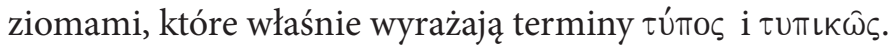

Drugim sposobem relektury Starego Testamentu proponowanym przez Pawła jest alegoria, która związane jest $\mathrm{z}$ typologią, czasem wręcz traktowana jako forma alegorii ${ }^{86}$. W Ga 4,24, kiedy Paweł pisze o Hagar i Sarze, stwierdza,

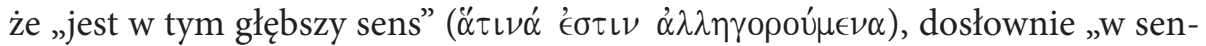
sie alegorycznym”, gdyż „kobiety wyobrażają dwa przymierza. Hagar oznacza przymierze z góry Synaj, które rodzi do niewoli. Ta właśnie Hagar to góra Synaj w Arabii. Symbolizuje ona obecną Jerozolimę, która wraz ze swymi dziećmi znajduje się w niewoli” (Ga 4,25). Użycie formy imiesłowowej od czasownika $\dot{\alpha} \lambda \lambda \eta \gamma \gamma \rho \rho^{\prime} \omega$ nadaje specyficzne znaczenie zastosowanej interpretacji, którą możemy nazwać alegoryczną. Niewątpliwie Paweł jest jednym z jej prekursorów na gruncie chrześcijańskim.

82 H. Langkammer, Apostoł Paweł, s. 231, zdaniem J. Gnilki, Paweł, s. 260 jest to raczej przykład „bardzo śmiałej interpretacji alegorycznej”

83 H. Langkammer, Jezus Chrystus, s. 33 proponuje przekład „obrazowo”.

84 Zob. M. Rosik, Pierwszy List, s. 314.

85 M. Simonetti, Między dosłownościa a alegorią, s. 22.

86 Na temat pochodzenia alegorii oraz jej związków z typologią, zob. A. Paciorek, Chrystocentryzm alegorii, s. 29-31; zob. także R.A. Pérez Márquez, L’Antico Testamento, s. 69-73. 
Warto jednak zwrócić uwagę, że Paweł nawet jeśli odwołuje się do alegorii to nie oznacza ona, jak u pisarzy pogańskich, całkowitej negacji sensu literalnego. Paweł podobnie, jak Filon Aleksandryjski, nie eliminuje sensu literalnego tekstu biblijnego, ale nakłada na niego nowe znaczenie. W ten sposób typologia i alegoria są do siebie bardzo zbliżone, a za M. Simonetti, można powiedzieć, że „typologia jest jednym $\mathrm{z}$ różnych sposobów mówienia alegorycznego. [...] Bowiem każda interpretacja, która jest typologiczna co do treści (ponieważ zauważa w jakiejś rzeczywistości ze ST typos rzeczywistości NT), jest alegoryczna co do metody hermeneutycznej (ponieważ daje tej rzeczywistości znaczenie, które nie jest znaczeniem literalnym)" 87 . W podobnym duchu wypowiada się Papieska Komisja Biblijna, kiedy stwierdza: „W Nowym Testamencie jest jedyna wzmianka o "wydarzeniach mających sens alegoryczny» (allēgoroumena $\mathrm{Ga}$ 4,24 ), ale wówczas chodzi faktycznie o typologię, to znaczy, że osoby wymienione w starym tekście są przedstawione jako zapowiedź przyszłych rzeczywistości, przy czym w żadnym wypadku nie jest poddawane w wątpliwość ich historyczne istnienie. Inny tekst Pawła wykorzystuje alegorię celem zinterpretowania pewnego szczegółu z Prawa (1 Kor 9,9). Jednak ta metoda nigdy nie została przez niego przyjęta w formie ogólnej orientacji”"88.

\section{Teologiczne konsekwencje Pawłowego rozumienia Starego Testamentu}

Na koniec pytamy zatem o teologiczne implikacje Pawłowego rozumienia Starego Testamentu. Jest on przede wszystkim Słowem Bożym, które nie przebrzmiało i nie może milczeć. Niesie bowiem w sobie obietnice samego Boga, odnoszące się do całej historii zbawienia. Jak pisze J. Gnilka, powoływanie się na Stary Testament „jest podyktowane koniecznością historiozbawczą. W grę wchodzi tu tożsamość Boga. Paweł jest przekonany, że Bóg Izraela, który ukazywał się w Piśmie, jest również Bogiem i Ojcem naszego Pana Jezusa Chrystusa, tym, który się w Nim objawił w sposób definitywny" ${ }^{99}$. Stary Testament pomaga nam zatem odkryć Boga wiernego, prawdomównego, dotrzymującego danego słowa i konsekwentnie realizującego plan zbawienia świata.

Stary Testament mając charakter prorocki i przede wszystkim chrystoperspektywiczny staje się przygotowaniem Ewangelii i Kościoła, który w historii zbawienia opowiedzianej $\mathrm{w}$ Pierwszym Testamencie odnajduje prehistorię

M. Simonetti, Między dosłownością a alegorią, s. 22-23, przypis 32. 
dzieła zbawczego w Jezusie oraz wiary chrześcijańskiej. „Nie ulega wątpliwości, że przy interpretowaniu Pisma dla Pawła decydujące jest wydarzenie Chrystusa. Nie interesuje go historyczno-krytyczny sens Pism - taka interpretacja pojawi się dopiero w epoce nowożytnej; wychodząc z przesłanek chrystologicznych, w Starym Testamencie Paweł odkrywa odniesienia do Chrystusa. W takiej interpretacji zasadnicze znaczenie mają dwie podstawowe reguły: w Starym Testamencie istnieją wzorce dla sposobu działania Boga w teraźniejszości. Ponieważ jest to ten sam Bóg, dawniej działał tak samo, jak działa obecnie. Dochodzi jeszcze do tego świadomość życia w czasach eschatologicznych, mesjańskich, i wszelkie działanie Boga opisywane w Piśmie mają taki właśnie horyzont. Pismo staje się świadkiem teraźniejszości"90.

Paweł poszukuje tego sensu dla teraźniejszości wyznawców Jezusa przy pomocy wspomnianych kluczy hermeneutycznych, zwłaszcza typologii i pokrewnej alegorii. W ten sposób stara się oddać i wyrazić teologicznie jedność i jednolitość Bożego działania w historii zbawienia, która konsekwentnie zdąża ku Jezusowi Chrystusowi, centrum i apogeum historii zbawienia. „Obietnica i typologia stanowią dla Pawła wspólny mianownik dla wszystkich pism Starego Testamentu, łącząc je w jedno «Stare Przymierze» (2 Kor 3,14)" "11. Zastosowanie podejścia typologicznego i alegorycznej, przynajmniej w ujęciu Pawłowym proponuje egzegezę tekstów starotestamentowych między „dosłownością a alegorią". Nigdy Paweł nie neguje sensu wyrazowego i historycznego znaczenia przywoływanych wydarzeń, osób, instytucji Starego Testamentu, ale w świetle Chrystusa zmartwychwstałego szuka ich nowego sensu duchowego.

\section{Zakończenie}

Podejście Pawła do Starego Testamentu jako obietnicy, która odczytywana w świetle misterium paschalnego Chrystusa, wypełnia się, w istotny sposób wyznacza kierunek, jaki będzie podążać chrześcijańska tradycja interpretacji Starego Testamentu. Liczni autorzy będą wprost powoływali się na Apostoła, uprawiając alegoryczną czy typologiczną interpretację Biblii ${ }^{92}$. Odziedziczyli oni nie tylko sposób podejścia do Starego Testamentu, ale także przekonanie o możliwości pogodzenia obu sensów wyrazowego i duchowego: „Kiedy Paweł, a za jego przykładem inni chrześcijanie rozróżniali pomiędzy literą a duchem, pomiędzy historią a misterium, pomiędzy figurą a wypełnieniem, pomiędzy

\footnotetext{
90 Ibidem, s. 262.

91 H. Langkammer, Jezus Chrystus, s. 35.

92 Konkretne przykłady w A. Paciorek, Chrystocentryzm alegorii, s. 31-33.
} 
cieniem a prawdą, nie głosili bynajmniej, sugerując się platońskim rozróżnieniem pomiędzy opinią a poznaniem, jakoby obydwa te sensy wykluczały się nawzajem tak jak wykluczają się rzeczywistość i pozór, prawda i fałsz, ale uznawali w pełni rzeczywistość wydarzeń na obu omawianych poziomach"93. Takie podejście interpretacyjne jest postulowane także dzisiaj w lekturze i relekturze Starego Testamentu ${ }^{94}$. Myśl Pawła pozostaje aktualna i cenna także dla naszego rozumienia i odczytywana Pierwszego Testamentu. „Wiedziony nie tylko przez historyczne znaczenie tekstu, ale przez jego Boski autorytet, przez potrzebę aktualizacji przesłania biblijnego, przez siłę literackich skojarzeń i przez chrystologiczną wizję historii odkupienia, Paweł zdołał zarówno przedstawić prawdę Ewangelii, jak i pouczyć lud Boży, jak powinno się czytać Pismo Święte"95.

W podsumowaniu naszych rozważań warto przytoczyć fragment adhortacji Benedykta XVI, który syntetycznie ujmuje problematykę relacji między Starym i Nowym Testamentem, odwołując się także do myśli Apostoła Pawła: „Odnośnie do jedności Pism w Chrystusie jest rzeczą konieczną, by zarówno teologowie, jak i duszpasterze byli świadomi relacji między Starym i Nowym Testamentem. Przede wszystkim jest oczywiste, że sam Nowy Testament uznaje Stary Testament za słowo Boże i dlatego przyjmuje autorytet świętych Pism narodu żydowskiego. Uznaje je implicite, posługując się tym samym językiem i nawiązując często do fragmentów owych Pism. Uznaje je w sposób wyraźny, przytacza bowiem wiele jego fragmentów i posługuje się nimi w argumentacji. Tak więc argumentacja opierająca się na tekstach Starego Testamentu stanowi w Nowym Testamencie decydującą wartość, przewyższającą rozumowanie czysto ludzkie. W czwartej Ewangelii Jezus stwierdza, że «Pisma nie można od-

93 Ibidem, s. 33.

94 Papieska Komisja Biblijna, Interpretacja Biblii w Kościele, s. 65 (IIB2) stwierdza jednoznacznie, że lektura duchowa wspólnotowa lub indywidulana jest w stanie odkryć prawdziwy sens duchowy tekstów biblijnych, jeżeli respektuje i uwzględnia „trzy płaszczyzny rzeczywistości: tekst biblijny, tajemnica paschalna i obecne okoliczności życia w Duchu”. Na temat starożytnej egzegezy, która starała się znaleźć sens duchowy w najmniejszych szczegółach tekstów biblijnych, posługując się metodami rabinicznymi lub czerpiąc natchnienie z alegoryzmu hellenistycznego, Komisja wypowiada się z dużą ostrożnością stwierdzając, że „współczesna egzegeza nie może przyznać wartości interpretacyjnej takim próbom”. Dokument stwierdza jednak, że „jednym z możliwych aspektów sensu duchowego jest aspekt typologiczny, o którym zazwyczaj się mówi, że nie należy on do samego Pisma Świętego, ale do rzeczywistości wyrażonej przez Pismo: Adam figurą Chrystusa (por. Rz 5,14), potop figurą chrztu (1 P 3,20-21) itd. Faktycznie związek typologii zazwyczaj zasadza się na sposobie, w jaki Pismo Święte opisuje starodawną rzeczywistość (por. głos Abla: Rdz 4.10; Hbr 11,4; 12,24), nie zaś tylko pisze o tej rzeczywistości. W konsekwencji chodzi wówczas o sens Pisma Świętego".

95 M. Silva, Stary Testament u Pawła, s. 791. 
rzucić» (J 10,35), a św. Paweł precyzuje w szczególności, że Objawienie Starego Testamentu jest nadal aktualne dla nas chrześcijan (por. Rz 15,4; 1 Kor 10,11). Ponadto stwierdzamy, że «Jezus z Nazaretu był Żydem, a Ziemia Święta jest macierzystą ziemią Kościoła»; korzenie chrześcijaństwa znajdują się w Starym Testamencie i chrześcijaństwo zawsze czerpie pokarm z tych korzeni. Dlatego zdrowa nauka chrześcijańska zawsze odrzucała wszelkie odradzające się formy marcjonizmu, który na różne sposoby przeciwstawia Stary Testament Nowe$\mathrm{mu} " 96$.

\section{Bibliografia}

Beale G.K., John's Use of the Old Testament in Revelation, Sheffield 1998.

Benedykt XVI, Adhortacja apostolska Verbum Domini. O Stowie Bożym w życiu i misji Kościoła, Kraków 2010.

de Lubac H., Pismo Święte w tradycji Kościoła, Kraków 2008.

Ellis E.E., Interpretacja Starego Testamentu w Nowym, w: W.R. Farmer (red.), Międzynarodowy komentarz do Pisma Świętego, Warszawa ${ }^{2} 2001$, s. 49-58.

Gnilka J., Paweł $z$ Tarsu. Apostoł i świadek, Kraków 2001.

Grilli M., Quale rapporto tra i due Testamenti? Riflessione critica sui modelli ermeneutici classici concernenti l'unità delle Scritture, Bologna 2007.

Hanson A.T., Typologia, w: B.M. Metzger, M.D. Coogan (red.), Słownik wiedzy biblijnej, Warszawa 1996, s. 780.

Hays R.B., Echoes of Scripture in the Letters of Paul, New Haven-London 1989.

Jelonek T., Wprowadzenie do listów Pawłowych, Kraków 1998.

Karczewski M., Reinterpretacja Księgi Rodzaju w Apokalipsie św. Jana, Olsztyn 2010.

Korzec C., Przeznaczony do Ewangelii, CTO 2 (2008), s. 71-87.

Langkammer H., Apostoł Pawet i jego dzieło, Opole 2001.

Langkammer H., Jezus Chrystus i Jego Kościót w nauczaniu św. Pawła Apostoła, Lublin 2011.

Langkammer H., List do Rzymian, Lublin 1999.

Légasse S., L'épître de Paul aux Romains, Paris 2002.

McNeil B., Typologia, w: R.J. Coggins, J.L. Houlden (red.), Słownik hermeneutyki biblijnej, Warszawa 2005, s. 894.

Paciorek A., Chrystocentryzm alegorii chrześcijańskiej w starożytnej hermeneutyce biblijnej, RT XLIV (1997) 1, s. 29-42.

Paciorek A., Paweł Apostoł - pisma, cz. I, Tarnów²1997.

Papieska Komisja Biblijna, Interpretacja Biblii w Kościele. Dokument Papieskiej Komisji Biblijnej z komentarzami biblistów polskich, R. Rubinkiewicz (red.), Warszawa 1999.

96 Benedykt XVI, Adhortacja apostolska, s. 47-48 (nr 40). 
Papieska Komisja Biblijna, Naród żydowski i jego Święte Pisma w Biblii chrześcijańskiej, Kielce 2002.

Penna R., Lettera ai Romani, t. I, Rm 1-5, Bologna 2007.

Pérez Márquez R.A., L’Antico Testamento nell'Apocalisse. Storia della ricerca, bilancio e prospettive, Assisi 2010.

Pitta A., Lettera ai Romani, Milano ${ }^{2} 2001$.

Podeszwa P., Memoria scripturarum w opowiadaniu o prorockim powołaniu św. Pawła (Dz 26,12-18), StByd 6 (2012), s. 7-28.

Rakocy W., „Nomos” $i$ „ho nomos” w Liście do Rzymian, BPTh 3 (2010), s. 11-23.

Rakocy W., Nomos i ho nomos w listach Pawłowych, BibAn 1 (2011), s. 167-184.

Rakocy W., Paweł Apostoł. Chronologia życia i pism. Częstochowa 2003.

Robeck C.M., Proroctwo, prorokowanie, w: G.F. Hawthorne, R.P. Martin, D.G. Reid (red.), Słownik teologii św. Pawła, Warszawa 2010, s. 652-659.

Rosik M., Pierwszy List do Koryntian, Częstochowa 2009.

Shrenk G., $\gamma \rho \alpha ́ \phi \omega$, w: Kittel G., Friedrich G. (red.), Grande Lessico del Nuovo Testamento, t. II, Brescia 1966, k. 623-654.

Silva M., Stary Testament u Pawła, w: G.F. Hawthorne, R.P. Martin, D.G. Reid (red.), Słownik teologii św. Pawła, Warszawa 2010, s. 779-792.

Simonetti M., Między dosłownością a alegorią, Kraków 2000.

Św. Pawet - przeznaczony do Ewangelii, wywiad z ks. Bp. Zbigniewem Kiernikowskim, rozmawiają K. Pek MIC i ks. W. Węckowski, „Pastores” 41 (2008) 4, s. 82-93.

Unterman A., Encyklopedia tradycji i legend żydowskich, Warszawa 2000. 